\title{
Evaluation of commercial floating treatment wetland technologies for nutrient remediation of stormwater
}

\author{
Jeanette Lynch $^{\text {a }}$, Laurie J. Fox ${ }^{\text {b,* }}$, James S. Owen Jr. ${ }^{b}$, David J. Sample ${ }^{c}$ \\ a Hampton Roads Agricultural Research and Extension Center, Virginia Polytechnic Institute and State University, 1444 Diamond Springs Road, Virginia Beach, \\ VA 23455,USA \\ b Department of Horticulture, Hampton Roads Agricultural Research and Extension Center, Virginia Polytechnic Institute and State University, 1444 Diamond \\ Springs Road, Virginia Beach, VA 23455,USA \\ ${ }^{\mathrm{c}}$ Department of Biological Systems Engineering, Hampton Roads Agricultural Research and Extension Center, Virginia Polytechnic Institute and State \\ University, 1444 Diamond Springs Road, Virginia Beach, VA 23455,USA
}

\section{A R T I C L E IN F O}

\section{Article history:}

Received 22 July 2014

Received in revised form 8 October 2014

Accepted 9 November 2014

Available online $\mathrm{xxx}$

\section{Keywords:}

Nitrogen

Phosphorus

Pollution

Phytoremediation

Beemat

BioHaven ${ }^{\mathbb{B}}$

\begin{abstract}
A B S T R A C T
Floating treatment wetlands (FTWs) are a relatively new water treatment practice that consists of emergent wetland plants planted on floating mats constructed of buoyant material. This study utilized batch-fed mesocosms, with a seven-day retention time, to investigate the total nitrogen (TN) and phosphorus (TP) remediation capability of two commercially available FTW technologies using runoff from a combined irrigation holding and stormwater retention pond. Nutrients in the pond water are attributed to runoff from nearby fertilized research plots upgradient. The FTW technologies included Beemats (Beemats LLC, New Smyrna Beach, FL, USA) and BioHaven ${ }^{\circledR}$ floating islands (Floating Island International, Inc. Shepard, MT, USA) planted with Juncus effusus (soft rush). Due to an increase in TN and $\mathrm{TP}$ in the initial phase of the experiment during the plant establishment phase (weeks 1-8), BioHaven ${ }^{\mathbb{R}}$ nutrient removal was lower over the entire experimental period than the Beemat treatment. Differences between the two treatments, such as mat material or substrate materials and/or additives may account for this difference. The BioHaven ${ }^{\mathbb{R}}$ FTW removed $25 \%$ and $4 \%$, while the Beemat removed $40 \%$ and $48 \%$ of the TN and TP, respectively expressed in terms of net removal over the entire study. During the plant growth season (weeks 9-18 of the study), the two technologies showed similar nutrient removal rates: for $\mathrm{TN}: 0.026 \pm 0.0032$ and $0.025 \pm 0.0018$, and for TP:0.0074 \pm 0.00049 and $0.0076 \pm 0.00065 \mathrm{~g} / \mathrm{m}^{2} /$ day for Beemat and Biohaven ${ }^{\mathbb{R}}$, respectively. A control treatment, meant to reflect nutrient removal within the pond without the presence of plants, yielded $28 \%$ and $31 \%$ removal of TN and TP, respectively. Thus, the Beemat mat yielded a significant positive net removal of TN and TP. The BioHaven ${ }^{\circledR}$ biomass was significantly greater than the Beemat treatment. Both treatments showed greater biomass accumulation in shoots rather than in roots. Plant nutrient content was similar between the two treatments.
\end{abstract}

(c) 2014 Elsevier B.V. All rights reserved.

\section{Introduction}

Urban runoff is a growing contributor of nonpoint source pollution (NPS) to receiving waters in the United States (Novotny,

Abbreviations: ANOVA, Analysis of Variance of means; BMP, best management practice; EC, conductivity; DO, dissolved oxygen; EMC, Event Mean Concentration; ET, evapotranspiration; FTW, floating treatment wetland; HRAREC, Hampton Roads Agriculture Research and Extension Center; MS4, Municipal Separate Storm Sewer System; NPDES, National Pollutant Discharge Elimination System; N, nitrogen; P, phosphorus; TN, total nitrogen; TMDL, total maximum daily load; TP, total phosphorus; U.S.EPA, United States Environmental Protection Agency.

* Corresponding author. Tel.: +1 757363 3807; fax: +1 7573633950.

E-mail addresses: jflynch@cox.net (J. Lynch), ljfox@vt.edu (L.J. Fox), jsowen@vt.edu (J.S. Owen Jr.), dsample@vt.edu (D.J. Sample).
2003). Urban runoff, also known as stormwater, is generated from impervious surfaces such as roads, sidewalks, driveways, parking lots and rooftops.With the removal of vegetation and the sealing of the soil surface by pavement and buildings, infiltration decreases, resulting in increased runoff rates and volumes, and reduced baseflow to streams (Fletcher et al., 2013; Yang et al., 2011). Urban development contributes to: flooding (Meierdiercks et al., 2010), decline of base flows (Hamel et al., 2013), bank erosion and downcutting (Cianfrani et al., 2006; Navratil et al., 2013; Nelson and Booth, 2002); and declining water quality from excess sediment, nutrients, and heavy metals (Carey et al., 2013; Hatt et al., 2011), resulting in a decline in diversity of aquatic biota (Alberti et al., 2007). Urban runoff transports a variety of pollutants from pavement wear, fuel combustion, deicing salts, nutrients 
from fertilizer, sediment and organic matter (Burton and Pitt, 2002; Driver and Tasker, 1990; Waschbusch, 1999).

Runoff water quality is influenced by site land use and can be estimated by consulting historical datasets. One of these, the National Urban Runoff Program (NURP), assessed 29 prototype urban sites (U.S. EPA, 1983) during the 1970s and 1980s. Observed event mean concentrations (EMCs) of TP and TN for urban open land were $2.2 \pm 1.5 \mathrm{mg} / \mathrm{L}$ and $0.30 \pm 0.16 \mathrm{mg} / \mathrm{L}$, respectively (U.S. EPA, 1983). TN is assumed to be the summation of oxidized nitrogen $\left(\mathrm{NO}_{x}\right)$ and total Kjeldahl nitrogen (TKN). AMWCOG (Metropolitan Washington Council of Governments, 1983) report showed similar ranges for TN:0.78-9.70 mg/L, and TP:0.15$1.58 \mathrm{mg} / \mathrm{L}$. More recent data is provided within the National Urban Runoff Quality Database (Pitt, 2009). This source was created from reporting entities under the National Pollutant Discharge Elimination System (NPDES) MS4 phase I program. From this database, EMC values were $2.96 \mathrm{mg} / \mathrm{L}$ for TN and $0.27 \mathrm{mg} / \mathrm{L}$ for TP for Virginia coastal plain urban residential land (Hirschman et al., 2008).

Excess $\mathrm{N}$ and $\mathrm{P}$ can adversely impact receiving waters. For example, negative impacts have occurred within the Chesapeake Bay estuary due to nutrient ( $\mathrm{N}$ and $\mathrm{P}$ ) and sediment pollution (i.e. suspended solids). As a result, a total maximum daily load (TMDL) for those pollutants was established (U.S. EPA, 2010). The reductions imposed by the TMDL will require significant efforts from Municipal Separate Storm Sewer System (MS4) programs. A key issue is addressing legacy development, i.e., those properties which have limited stormwater treatment. Development from the mid-70s through the 2000s used retention ponds (i.e. wet ponds) almost exclusively as the best management practice (BMP) of choice for water quality treatment (Schueler, 2011). Retention ponds hold water year-round, provide storage to attenuate peak runoff rates, and provide limited water quality treatment through sedimentation. While they are effective at treating pollutants that are attached to sediment particles, they are not effective at treating dissolved pollutants in runoff (Shilton, 2005). Opportunities exist for a BMP that could enhance retention pond performance and improve water quality while providing reductions in nutrient and sediment loads to receiving waters without requiring additional space.

Available land for created wetlands and stormwater retention ponds is limited in urban areas, and land acquisition is a major cost component of an urban BMP (Thurston, 2006). Recent interest has focused upon floating treatment wetlands (FTWs) for treatment of stormwater (Borne et al., 2013; Wang and Sample, 2014; White and Cousins, 2013; Winston et al., 2013). FTWs are a new tool for $\mathrm{N}$ and $\mathrm{P}$ management and can be employed in existing retention ponds. A key advantage of FTWs is they do not require additional land area. FTWs consist of emergent wetland plants growing on buoyant mats which are placed on the water surface. The plants grow through the mat and into the water, assimilating nutrients directly from the water. In addition, the plant roots create a large surface area beneath the floating mat for nutrient adsorption and biofilm attachment, mimicking natural wetlands (Headley and Tanner, 2006, 2012). Generally, the mechanisms for N removal in a FTW are assimilation and denitrification and $\mathrm{P}$ is removed by assimilation and sorption (Jayaweera and Kasturiarachchi, 2004). Borne (2014) suggests sorption, entrapment in roots, and settling are more dominant P removal processes; Wang and Sample (2014) suggest decomposition and sorption onto attached root-based biofilms. In a field scale FTW application, Borne et al. (2013) found that significant denitrification occurred in summers, when dissolved oxygen was low, resulting in a high $\mathrm{N}$ removal during this period. According to Stewart et al. (2008), laboratory scale testing of a proprietary FTW (BioHaven ${ }^{\circledR}$ Floating Island) removed $117.8 \mathrm{~g} / \mathrm{m}^{2} /$ $\mathrm{d}$ of nitrate $\left(\mathrm{NO}_{3}\right), 3.0 \mathrm{~g} / \mathrm{m}^{2} / \mathrm{d}$ of ammonium $\left(\mathrm{NH}_{4}\right)$, and $4.8 \mathrm{~g} / \mathrm{m}^{2}$ of phosphate $\left(\mathrm{PO}_{4}\right)$ from domestic wastewater. Early research of FTWs was directed at treating agricultural wastewater. Hubbard et al. (2004) applied FTWs (planted with cattail, Typha sp.) to a wastewater lagoon treating swine effluent where they removed 534 and $79 \mathrm{~g} / \mathrm{m}^{2}$ of $\mathrm{N}$ and $\mathrm{P}$, respectively with a 14 day hydraulic retention time.

Additional advantages of FTWs as a stormwater management tool are that they can easily fit in existing retention ponds and adjust to varying water depths typical of event-driven stormwater systems (Headley and Tanner, 2012; White and Cousins, 2013). These advantages make FTWs appealing as a potential stormwater BMP for enhancing treatment within existing stormwater retention ponds. The Florida Department of Environmental Protection has assigned a $12 \%$ treatment credit for FTWs towards meeting watershed $\mathrm{N}$ and $\mathrm{P}$ nonpoint source reduction goals (Wanielista et al., 2012). Hunt et al. (2012) recommended an additional 5\% total nitrogen (TN) and total phosphorus (TP) removal credit for FTWs

Table 1

Summary of treatment type and nutrient removal rates of selected FTW studies.

\begin{tabular}{|c|c|c|}
\hline Reference & Treatment Type & Results \\
\hline $\begin{array}{l}\text { Chang et al. } \\
\text { (2012a) }\end{array}$ & $\begin{array}{l}\text { Mesocosm study using BioHaven }{ }^{\mathbb{B}} \text { mat with soft rush (Juncus effusus) and } \\
\text { pickerelweed (Pontederia cordata) subjected to simulated stormwater. }\end{array}$ & $\begin{array}{l}\text { Average removal rates were } 30-31 \% \text { TN and } 49-52 \% \text { TP with } 5 \% \\
\text { surface area coverage }{ }^{\text {a }} \text {. }\end{array}$ \\
\hline $\begin{array}{l}\text { Chang et al. } \\
\text { (2012b) }\end{array}$ & $\begin{array}{l}\text { Mesocosm study using Beemat mat with canna (Canna flaccida) and soft rush (Juncus } \\
\text { effusus) subjected to simulated stormwater. }\end{array}$ & $\begin{array}{l}\text { Concluded a } 5 \% \text { surface area coverage can achieve } 61 \% \text { TN and } \\
53 \% \text { TP removal within } 15 \text { day time span }{ }^{\text {a. }} \text {. }\end{array}$ \\
\hline $\begin{array}{l}\text { Chua et al. } \\
\text { (2012) }\end{array}$ & $\begin{array}{l}\text { Mesocosm and field studies using Bestmann Green Systems }{ }^{\mathrm{TM}} \text { mat and three plant } \\
\text { species to remove nutrients in baseflow from an urban catchment area. }\end{array}$ & $\begin{array}{l}\text { Net nutrient reduction was } 8-40.8 \% \text { for TN and } 19-46 \% \text { for TP in } \\
\text { mesocosm study. }\end{array}$ \\
\hline $\begin{array}{l}\text { Headley and } \\
\text { Tanner } \\
(2007)\end{array}$ & $\begin{array}{l}\text { Mesocosm study using BioHaven }{ }^{\mathbb{R}} \text { mat and four plant species for removal of fine } \\
\text { particulates, copper and zinc from simulated stormwater. }\end{array}$ & $\begin{array}{l}\text { After } 6.7 \text { days, mean concentration reduction in planted } \\
\text { treatments was } 72-96 \% \text { for } \mathrm{NH}_{4}-\mathrm{N} \text { and } 20-51 \% \text { for dissolved } \\
\text { reactive phosphorus }{ }^{\mathrm{a}} \text {. }\end{array}$ \\
\hline $\begin{array}{l}\text { Wang and } \\
\text { Sample } \\
(2014)\end{array}$ & $\begin{array}{l}\text { Mesocosm study using floating PVC frame with plastic mesh and pickerelweed } \\
\text { (Pontedera cordata L.), softstem bulrush (Schoenoplectus tabernaemontani) and water } \\
\text { obtained from a stormwater retention pond. }\end{array}$ & $\begin{array}{l}\text { Planted and unplanted floating mats significantly improved } \\
\text { phosphorus and nitrogen removal efficiency compared to a } \\
\text { control.Planted treatments enhanced TN and TP removal } \\
\text { efficiency by } 8.2 \% \text { and } 18.2 \% \text {, respectively. }\end{array}$ \\
\hline $\begin{array}{l}\text { Wen and } \\
\text { Recknagel } \\
(2002)\end{array}$ & $\begin{array}{l}\text { Polyethylene foam floats with four creeping-stem water plant species in controlled- } \\
\text { environment growth chambers subjected to simulated agricultural drainage water. }\end{array}$ & $\begin{array}{l}\mathrm{P} \text { removal rates of } 0.043-0.086 \mathrm{~g} \mathrm{P} / \mathrm{m}^{2} / \text { day measured as } \mathrm{P} \\
\text { bioaccumulation in plant tissue. }\end{array}$ \\
\hline $\begin{array}{l}\text { White and } \\
\text { Cousins } \\
\text { (2013) }\end{array}$ & $\begin{array}{l}\text { Beemat mat with golden canna (Canna flaccida) and soft rush (Juncus effusus) in flow- } \\
\text { through troughs treated with simulated stormwater solution. }\end{array}$ & $\begin{array}{l}\text { Daily N load reduced by } 87.9 \% \text { and } 66.9 \% \text { and average daily } \mathrm{P} \\
\text { concentration reduced by } 75 \% \text { and } 45.5 \% \text { during } 2008 \text { and } \\
2009 \text { spring-fall season, respectively }{ }^{\mathrm{a}} \text {. }\end{array}$ \\
\hline $\begin{array}{l}\text { Winston et al. } \\
\text { (2013) }\end{array}$ & $\begin{array}{l}\text { BioHaven }{ }^{\mathbb{R}} \text { mats planted with a mixture of eight macrophytes and retrofit into two } \\
\text { urban stormwater ponds. }\end{array}$ & $\begin{array}{l}\text { Mean TP and TN were reduced by } 39-88 \% \text { and } 48-88 \% \text {, } \\
\text { respectively, in two separate ponds }{ }^{\mathrm{a}} \text {. }\end{array}$ \\
\hline
\end{tabular}

a Indicates total removal, including both FTW and pond. 


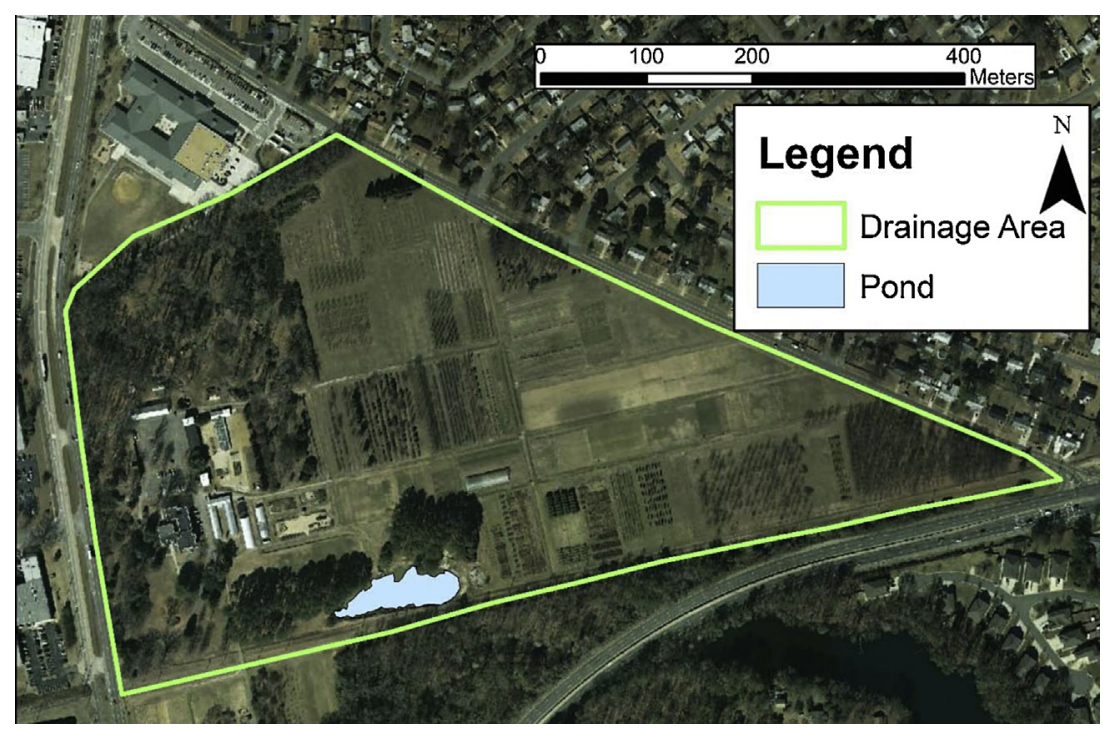

Fig. 1. Study site, and drainage area.

retrofits on existing stormwater retention ponds in North Carolina based upon a field study. A summary of these and additional studies that examined FTWs is provided in Table 1.

Several types of commercially-manufactured FTW systems are readily available. Although previous research studies have utilized various commercially available products (Table 1 ), there is a lack of published research comparing products utilizing specific manufacturer recommendations or guidelines. The objective of the study was to evaluate two commercially available FTW technologies using nutrient-polluted runoff collected in a retention pond, comparing performance of the mats and plants and subsequent TN and TP remediation over a five month period [18 weeks total, during the plant establishment phase (weeks 1-8), and the growth phase (weeks 9-18)].

\section{Materials and methods}

\subsection{Study site}

The study was conducted at the Virginia Tech Hampton Roads Agriculture Research and Extension Center (HRAREC) $\left(36^{\circ} 53^{\prime} \mathrm{N}\right.$, $76^{\circ} 10^{\prime} \mathrm{W}$ ) in Virginia Beach, Virginia, USA, shown in Fig. 1, which is in the Mid-Atlantic region of the U.S. During the experimental period, ambient air temperature averaged $24.3^{\circ} \mathrm{C}$. The drainage area contributing runoff to the pond is approximately 26.1 ha and is predominately open. Land use consists of forested areas (36.3\%), turf areas (32.9\%), ornamental horticultural crop plots (26.4\%), greenhouses and buildings (1.6\%), parking areas and driveways $(1.8 \%)$ and water $(1.1 \%)$; similar to a mixed use urban area. The impervious proportion is estimated to be $4.4 \%$. An influent TN of $1.00 \pm 0.01 \mathrm{mg} / \mathrm{L}$ and TP of $0.22 \pm 0.01 \mathrm{mg} / \mathrm{L}$ was observed at the study site. These and other minimum, mean, and maximum physical properties of the retention pond water are provided in Table 2. A study of parking areas in North Carolina (Passeport and Hunt, 2009), reported a mean TN of $1.57 \mathrm{mg} / \mathrm{L}$, and TP of $0.19 \mathrm{mg} / \mathrm{L}$, higher in TN, and lower in TP than this study. In a similar FTW study conducted in Fairfax, Virginia, Wang et al. (2014) reported a mixed commercial and residential urban area with a median TN of 1.15 , and a median TP of $0.15 \mathrm{mg} / \mathrm{L}$; also slightly higher in TN, and lower in TP than this study. The inflow concentrations have much less TN than the expected (from section 1) of $2.96 \mathrm{mg} / \mathrm{L}$, but match well with the expected TP concentration of $0.27 \mathrm{mg} / \mathrm{L}$ (Hirschman et al., 2008).

\subsection{Mesocosms and experimental treatments}

A batch-loaded mesocosm experiment was conducted from May 13 to September 16, 2013. The study included three treatments with four replicates following a completely randomized design. Twelve $189 \mathrm{~L}$ resin mesocosm tanks $(1.11 \mathrm{~m}$ long $\times 0.55 \mathrm{~m}$ wide $\times 0.46 \mathrm{~m}$ high) were installed under a $5.2 \times 8.5 \mathrm{~m}$ clear horticultural plastic shelter (X.S. Smith, Washington, NC) to prevent rainwater and debris from entering the mesocosms.

The shelter was constructed with open ends and sides to eliminate rainfall inputs to mesocosms. Bird netting was installed around the outside of the shelter to prevent disturbance by wildlife (Fig. 2). Mesocosm tanks were each supplied with $114 \mathrm{~L}$ of water from the HRAREC pond.The pond serves multiple purposes, including providing storage for irrigation and stormwater retention. A $5 \mathrm{~cm}$ semi-rigid hose was attached to floats with the intake end anchored to a post in the pond $4.9 \mathrm{~m}$ from the shoreline. The intake (with attached debris screen) was suspended $46 \mathrm{~cm}$ below the surface. The water depth at the post was $2.7 \mathrm{~m}$. Fresh pond water was pumped into a large central holding tank each week to create a homogenous source to fill the mesocosm tanks. Unused fill water was immediately drained from the central tank. The water surface within the mesocosm tanks was $0.48 \mathrm{~m}^{2}$ at a $0.26 \mathrm{~m}$ operational water depth. Tanks were emptied, pressure washed and refilled weekly with water from the retention pond to create 18 consecutive 7-day batches. For weeks 3 through 18, each

Table 2

Physicochemical properties of retention pondwater used to fill mesocosms.

\begin{tabular}{|c|c|c|c|c|c|c|}
\hline & Water Temp $\left({ }^{\circ} \mathrm{C}\right)$ & $\mathrm{DO}(\mathrm{mg} / \mathrm{L})$ & $\mathrm{EC}(\mu \mathrm{S} / \mathrm{cm})$ & $\mathrm{pH}$ & $\mathrm{TN}(\mathrm{mg} / \mathrm{L})$ & $\mathrm{TP}(\mathrm{mg} / \mathrm{L})$ \\
\hline Minimum & 23.5 & 5.5 & 107.4 & 6.7 & 0.64 & 0.09 \\
\hline Maximum & 29.8 & 8.9 & 163.8 & 8.7 & 1.49 & 0.45 \\
\hline Average & 27.2 & 7.4 & 136.9 & 7.3 & 1.00 & 0.22 \\
\hline
\end{tabular}




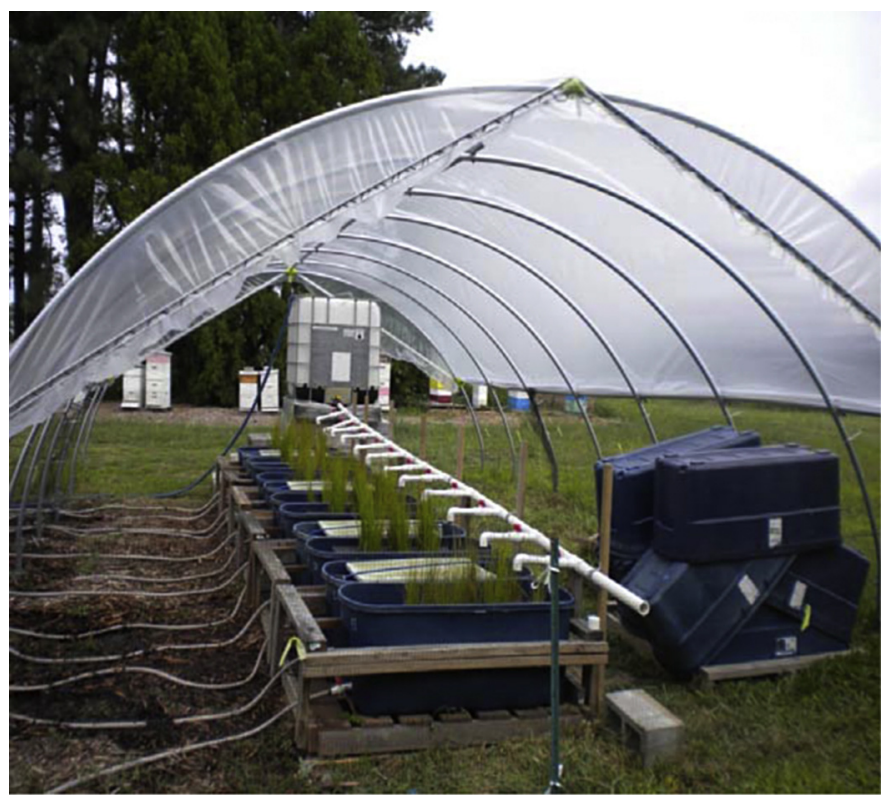

Fig. 2. Floating treatment wetland mesocosms, Virginia Tech research center, Virginia Beach, VA.

mesocosm was filled to its standard $(114 \mathrm{~L})$ volume with water from the retention pond at mid-week (day 3) to compensate for evaporative losses. All water volume changes in the mesocosms were attributed to evaporative losses. Before each tank was emptied, a third of the water was drained into a separate temporary tank. The FTW was transferred to this temporary holding tank to keep the roots from drying out while the research tank was emptied and washed. After the research tank was filled, the FTW was lifted from the temporary tank, held until it stopped dripping, then it was placed back into its research tank. The temporary tank was then washed and stored.

The FTW treatments consisted of $45.7 \mathrm{~cm} \times 68.6 \mathrm{~cm}$ floating mats, each with 9 equally spaced planting holes for an equivalent density of 27 plants $/ \mathrm{m}^{2}$. The mats covered $65 \%$ of the water surface. The floating treatment technologies used were Beemats (Beemats LLC, New Smyrna Beach, FL) and BioHavena ${ }^{\circledR}$ floating islands (Floating Island International, Inc. Shepard, MT). The Beemats system is comprised of $1.3 \mathrm{~cm}$ thick buoyant closed cell foam mats with pre-cut holes for specially designed plastic aerator pots which hold the coir fiber wrapped plant root balls. BioHaven ${ }^{\circledR}$ floating islands were made of a $16 \mathrm{~cm}$ thick, post-consumer plastic fibrous matrix injected with expanded polyurethane for buoyancy with pre-drilled planting holes. Nine $5 \mathrm{~cm}$ diameter rooted nursery plugs of Juncus effusus L. (soft rush) were planted into the equally spaced holes or pots on each mat according to the manufacturer's recommendations. For Beemats, the plant root balls, including the growing substrate, were wrapped in a $7.6 \mathrm{~cm} \times 15.2 \mathrm{~cm} \times 1.9 \mathrm{~cm}$ coir fiber sheet, inserted into the aerator pots, and then placed into the precut holes. For the BioHaven ${ }^{\circledR}$ mats, $237 \mathrm{~mL}$ of Sphagnum peat (Premier Horticulture Inc. Quakertown, PA) was placed into each pre-drilled planting hole, tamped lightly, and then the intact plant root ball including the growing substrate was inserted. Once planted, one floating mat was placed in each mesocosm tank. The BioHaven ${ }^{\mathbb{R}}$ mats were submerged with the top of the mat at the waterline and were maintained at this level for the first week to saturate the mat and peat moss and aid plant establishment. After the first week, the BioHaven ${ }^{\mathbb{R}}$ mats were allowed to float at their natural buoyant level with $8 \mathrm{~cm}$ of the mat submerged. The Beemat mats floated on top of the water with the planting pots submerged the entire study period.For this research, the approximate cost of the Beemat mat was $\$ 38 \mathrm{US} / \mathrm{m}^{2}$, and for Biohaven ${ }^{\circledR}$ was $\$ 377$ US $\mathrm{m}^{2}$, exclusive of vegetation, cups, and peat moss. The Biohaven ${ }^{\circledR}$ cost reflects its custom size and hole configuration for the experiment. The control treatment consisted of an opaque cover of $1.3 \mathrm{~cm}$ rigid pink polystyrene insulation board (Owens Corning, Toledo, $\mathrm{OH})$, equivalent in size $(45.7 \mathrm{~cm} \times 68.6 \mathrm{~cm})$ to the FTW mats. The board was suspended $15.2 \mathrm{~cm}$ above the mesocosm water surface, providing a similar area of shading to that of the floating mats. All treatments were replicated four times.

\subsection{Water sampling and analysis}

At the start of each seven-day batch, a $100 \mathrm{ml}$ grab sample of the retention pond water was collected from the central holding tank at a consistent $20.3 \mathrm{~cm}$ depth to represent the water quality at day 0 . On day 3, a $100 \mathrm{~mL}$ sample was collected from the newly filled central holding tank and from each mesocosm before the mesocosm water volumes were adjusted with water from the central tank to return them to a set volume. A $100 \mathrm{ml}$ grab sample was collected from each mesocosm at a consistent $20.3 \mathrm{~cm}$ depth on day 7. Samples were then placed in a cooler with an ice pack, transported to the lab and frozen until the end of the experimental period. Freezing is a common practice with water samples intended to be batch processed primarily for total $\mathrm{N}$ and $\mathrm{P}$ content, e.g., Roseen et al. (2009). Water samples were thawed and analyzed for TN and TP by automated flow injection analysis after persulfate digestion [persulfate digestion (low flow) methods, QuickChem ${ }^{\circledR}$ Method 10-107-04-4B and 10-115-01-4-B, respectively; Lachat Instruments, Loveland, CO, USA].

The physicochemical water properties (temperature $(T)$, dissolved oxygen (DO), electrical conductivity (EC) and $\mathrm{pH}$ ) of each mesocosm and the retention pond water were measured with an YSI Professional Plus multi-probe meter (Yellow Springs International Inc. Ohio, USA). Each mesocosm was measured on day 3, prior to the addition of compensation water, and on day 7 . Field measurements were conducted between 9:00 am and 12:00 pm eastern daylight time (EDT). The YSI meter was calibrated each day before measurements were taken, in accordance with procedures provided by the manufacturer. In addition, the retention pond (water source) and each mesocosm were measured every two hours from dawn-to-dusk (6:00 am to 8:00 pm EDT) on day 105 of the study (August 25, 2013) to obtain the diurnal flux of water physicochemical properties.

\subsection{Plant tissue sampling and analysis}

Shoots were collected from eight randomly selected plants prior to planting the FTW mat systems. The shoots were dried in a forced air oven at $58^{\circ} \mathrm{C}$ and weighed. At the end of the study, the maximum shoot heights and root lengths were measured in $\mathrm{cm}$ on four randomly selected plants for each mat system using a graduated ruler. Maximum shoot height was measured from the plant crown. Root length was measured from the bottom of the planting pot for the Beemats and from the lower mat surface for the BioHavens ${ }^{\mathbb{R}}$. To adjust for the difference in mat systems, the maximum crown-to-root tip length was calculated by adding the average distance between the bottom of the mat or pot and the plant crown to the measured root length. All above-crown shoots and below-planting pot (Beemat treatment) or below-mat (BioHaven ${ }^{\circledR}$ treatment) roots were collected. Plant tissue was rinsed with de-ionized water, dried to a constant weight $(72 \mathrm{~h})$ in a forced-air oven at $58{ }^{\circ} \mathrm{C}$. Initial plant shoots and final plant shoots and roots were sent to Brookside Laboratories, Inc. New Bremen, $\mathrm{OH}$, USA for analysis of nitrogen concentration using a carbon nitrogen analyzer and phosphorus concentration using inductively coupled plasma (ICP) spectroscopy after microwave digestion. 
Table 3

Physicochemical properties of mesocosm water on day 7.

\begin{tabular}{lllll}
\hline Treatment & Temp $\left({ }^{\circ} \mathrm{C}\right)$ & DO $(\mathrm{mg} / \mathrm{L})$ & $\mathrm{EC}(\mu \mathrm{S} / \mathrm{cm})$ & $\mathrm{pH}$ \\
\hline Beemat & & & & \\
Minimum & 18.8 & 2.63 & 104 & 6.30 \\
Maximum & 28.2 & 8.65 & 185 & 7.44 \\
Average & 24.9 & 5.40 & 141 & 6.77 \\
BioHaven & ${ }^{\circledR}$ & & & \\
Minimum & 17.8 & 1.56 & 101 & 5.93 \\
Maximum & 28.1 & 7.54 & 196 & 7.18 \\
Average & 24.6 & 4.19 & 134 & 6.62 \\
Control & & & & \\
Minimum & 17.4 & 5.65 & 104 & 6.75 \\
Maximum & 27.2 & 10.30 & 169 & 7.90 \\
Average & 23.8 & 7.53 & 139 & 7.25 \\
\hline
\end{tabular}

Shoot and root nutrient content was calculated by multiplying dry mass times $\mathrm{N}$ or $\mathrm{P}$ concentration.

\subsection{Data analysis}

Statistical analyses were performed using SAS JMP ${ }^{\circledR}$ Pro 10.0.2 software (SAS Institute, Inc. Cary, North Carolina, USA) and/or SigmaPlot 12.5 (San Jose, CA). Data were tested for normality using the Shapiro-Wilk goodness-of-fit test. One-way analysis of variance of means, (ANOVA), $t$-test, or Wilcoxon/ Kruskal-Wallis Tests (rank sums) were performed. The former parametric test was used when the normality assumption was accepted; the latter, nonparametric test was used when normality could not be assumed. Means for treatments were compared with the control using Dunnett's test. Unless otherwise specified, a $p$ value of 0.05 was used.

\section{Results and discussion}

The $\mathrm{N}$ and $\mathrm{P}$ removal, plant growth, and physicochemical responses of the Beemat and Biohaven ${ }^{\circledR}$ systems were compared and are presented in the following sections. Prior to introducing this comparison, however, it should be mentioned that the two FTW systems have entirely different purposes and designs. Beemat is a product that is less expensive and designed to be easily replaced after a season or two. In contrast, Biohaven ${ }^{\mathbb{R}}$ is a more expensive and more durable product, and is designed to be left in the pond for more than a few seasons. Both of these products have their advantages and disadvantages. While the differences in unit costs have been provided, other factors should be considered, including labor time and associated costs, vegetation costs, harvesting schedule (if applicable), substrate (if applicable), etc.

\subsection{Physicochemical responses}

The physicochemical properties of the mesocosm water, measured on day 7 weekly, are summarized in Table 3. The FTW treatments consistently had a higher average water temperature than the control treatments; likely due to the dark colored mats absorbing solar radiation, heating up and then transferring heat to the mesocosm water. This did not occur with the control treatment which had lighter-colored boards suspended over the mesocosm tank. The average DO and $\mathrm{pH}$ were lower in the FTW treatments

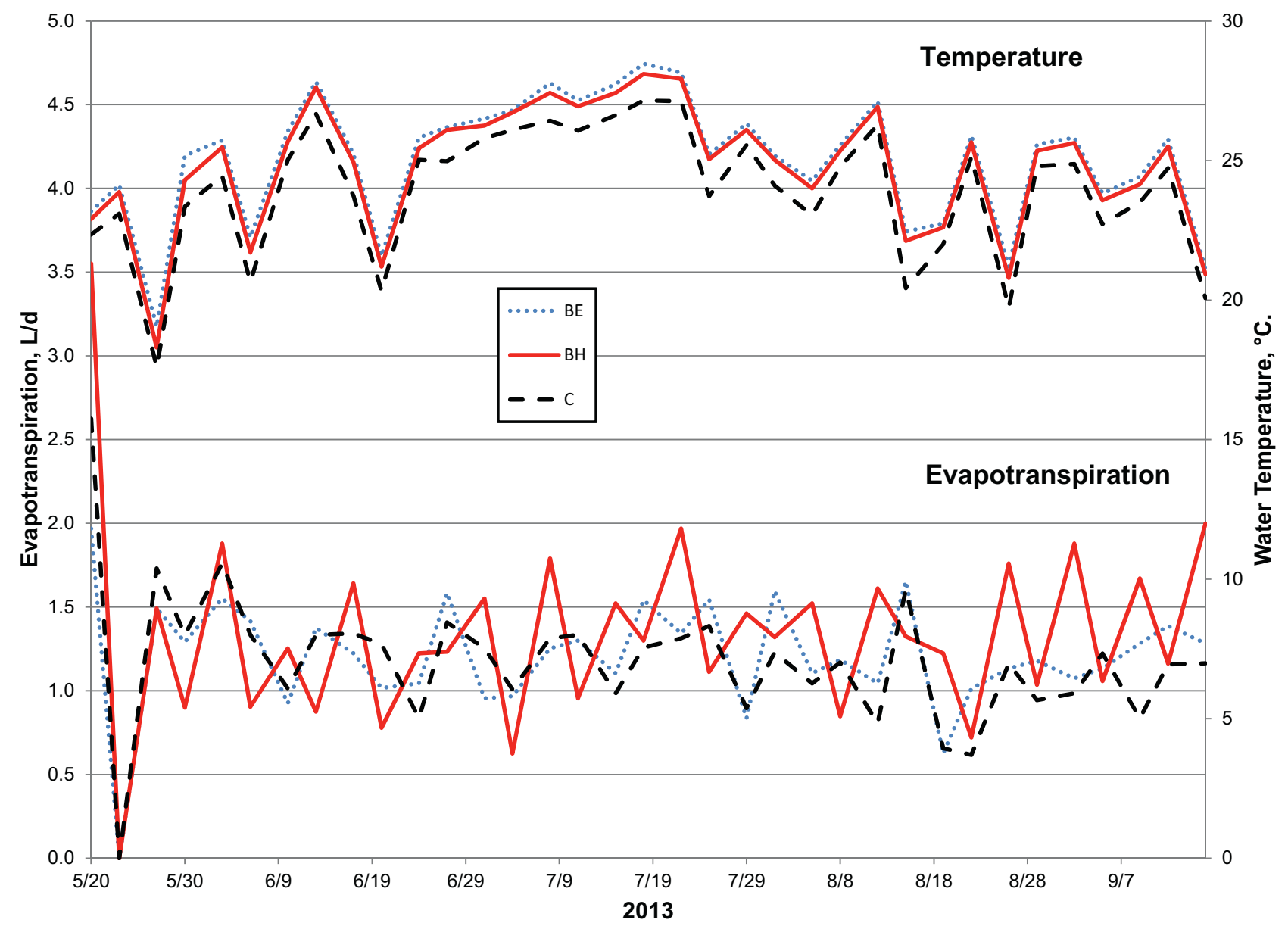

Fig. 3. Evapotranspiration and water temperature of mesocosms during the study. 

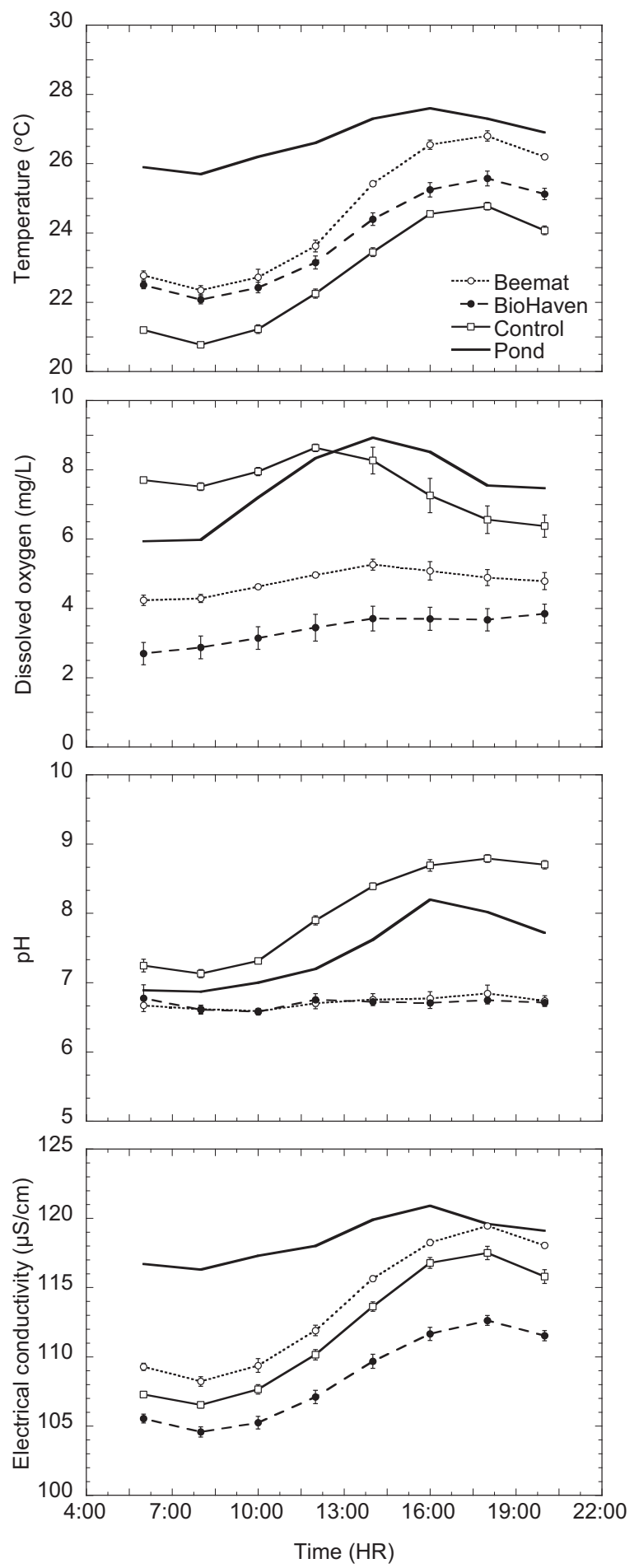

Fig. 4. Water quality parameters, as measured every two hours on August 25, 2013 (day 105), of the pond (P) and mesocosms containing Beemat (BE) Biohaven ${ }^{\mathbb{B}}(\mathrm{BH})$ or shaded control (C). Error bars represent standard error $(n=4)$.

than in the control treatment, possibly due to respiration from plant roots and microbial communities (Tanner and Headley, 2011). Electrical conductivity (EC) was highest, on average, in the Beemat.

BioHaven ${ }^{\mathbb{R}}$ treatments had significantly greater evapotranspirative losses than the Beemat and the control treatments (Fig. 3); the latter two track closely. The Beemat and control treatments were not significantly different from each other based on Dunnett's test. The greater ET loss for the BioHaven ${ }^{\circledR}$ treatment was possibly
Table 4

Mean cumulative mesocosm characteristics for the experimental period (18 weeks) ( $n=4$ for each treatment).

\begin{tabular}{lll}
\hline Treatment & $\begin{array}{l}\text { N load in Week 1-18 }\left(\mathrm{g} / \mathrm{m}^{2}\right. \\
\text { mat })\end{array}$ & P load in Week 1-18 $\left(\mathrm{g} / \mathrm{m}^{2} \mathrm{mat}\right)$ \\
\hline Beemat $_{\text {BioHaven }}{ }^{\mathrm{B}}$ & $6.40 \mathrm{a}$ & $1.39 \mathrm{a}^{\mathrm{a}}$ \\
Control $^{\mathrm{a}}$ & $6.35 \mathrm{~b}^{\mathrm{a}}$ & $1.38 \mathrm{~b}^{\mathrm{a}}$ \\
\hline
\end{tabular}

a Means with a different letter are significantly different from each other at $p<0.05$.

due to the wicking effect of the fibrous mat. In terms of temperature, Beemat and BioHaven ${ }^{\mathbb{R}}$ tended to be significantly higher than the control (Fig. 3). Beemat and BioHaven ${ }^{\circledR}$ were significantly different from the control, and neither is differentiable from the other. Again, this could be attributed to the thermal properties of the FTW mats which were black and absorptive and in contact with the water; and thus able to transfer heat. This phenomenon was not observed in Borne et al. (2013) and Winston et al. (2013), and may be explained by the fact that those were field-scale studies. A small mesocosm setup may magnify the temperature differences. The larger amount of biomass on the BioHaven ${ }^{\circledR}$ mats could also have impacted the mesocosm temperature, but it wouldn't have until later in the study, which accounts for the ET difference in August.

The diurnal variation in water physicochemical properties of the mesocosms is shown in Fig. 4. The water temperature and EC were lower in the mesocosms than the pond, but with greater diurnal variation. The water temperature was significantly higher in both FTW treatments than the control. The DO and pH in the FTW treatments were significantly lower than the control, lower than the pond, and showed significantly less diurnal variation. The $\mathrm{pH}$ in the control treatment was higher than the pond. Water temperature, DO and $\mathrm{C}$ were significantly higher in the Beemat treatments than the BioHaven ${ }^{\circledR}$ treatments. The $\mathrm{pH}$ was similar between the two FTW treatments.

\subsection{Nitrogen and phosphorus removal}

Cumulative $\mathrm{N}$ and $\mathrm{P}$ loads for the entire experimental period were significantly greater for the Beemat and control treatments than the BioHaven ${ }^{\mathbb{R}}$ treatment (Table 4). Cumulative nutrient removal over the experimental period is shown in Fig. 5. A notable inflection of the curves is evident around week eight suggesting the following classification: a plant establishment phase (weeks 18 ) and a growth phase (weeks 9-18). Week 8 was selected as the point of inflection, as this is when the line began to separate from the control, and thus is identifiable and has a relatively uniform slope. The $R^{2}$ values for the linear fit of nutrient load removed for weeks 9-18 are reported in Table 5. During weeks 1-8 there was an increase in $\mathrm{N}$ and $\mathrm{P}$ concentrations in the BioHaven ${ }^{\circledR}$ treatments, while cumulative removal was similar for the Beemat and control treatments (Table 5). Once plants were established, Beemat and BioHaven ${ }^{\circledR}$ treatments showed similar cumulative nutrient removal during weeks 9-18 with both treatments showing significantly greater removal than the control treatment (Table 5). Since the mesocosms received the same water, had the same volumes, the same plants, and were treated the same, the discrepancy in nutrient loading between the two treatments is likely due to the remaining differences; which include the substrate (peat moss in the Biohaven ${ }^{\mathbb{R}}$ treatment versus coir fiber in the Beemat) and the mat material. Further research is needed to identify the source of this effect.

These results contrast with those of Borne et al. (2013) and Winston et al. (2013) which were field-scale applications of FTWs. It is likely that whatever factor caused the discrepancy was 

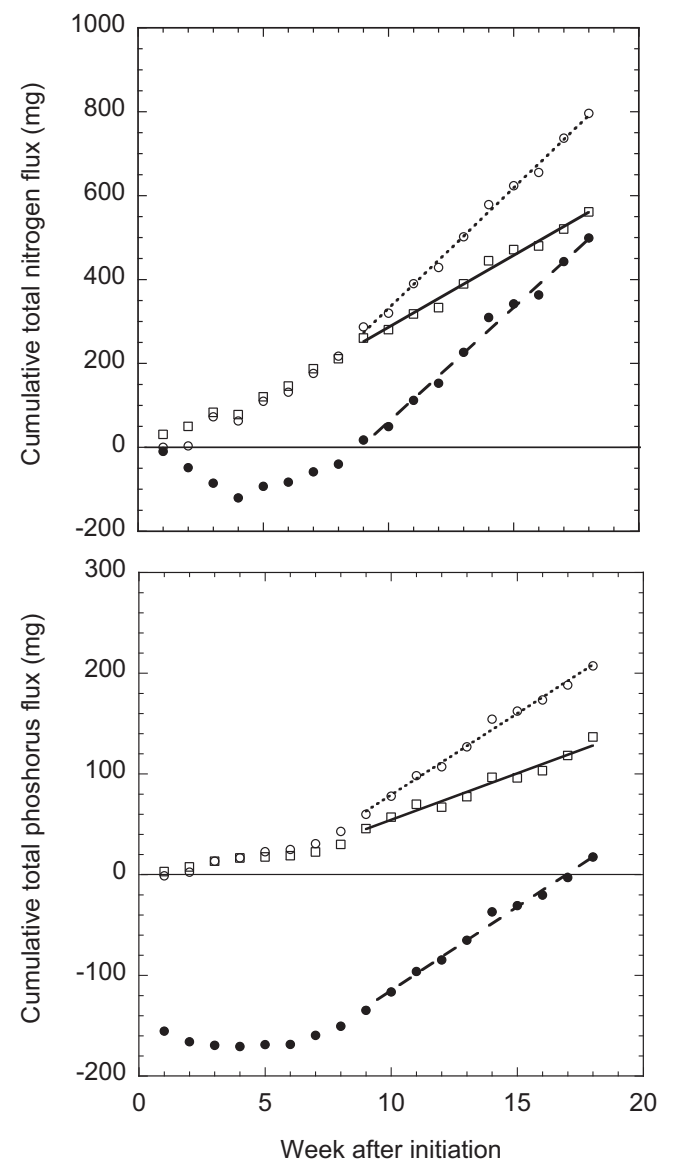

$\cdots \mathrm{O}-\mathrm{BE} \quad \rightarrow-\mathrm{BH} \quad \square-\mathrm{C}$

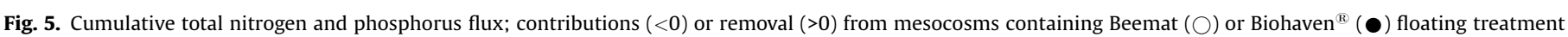

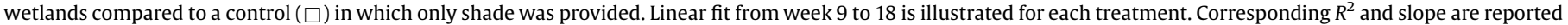
in Table 4.

magnified by the small volumes of the mesocosms, at least initially. In a pond, we would expect the larger volume to dilute this effect, which is consistent with the first order kinetic model presented in Wang and Sample (2013) which includes pond volume as a factor in predicting performance.

In terms of overall mass removal, BioHaven ${ }^{\circledR}$ FTW removed $25 \%$ and $4 \%$, of TN and TP, while the Beemat removed $40 \%$ and $48 \%$ of the TN and TP, respectively. A control treatment, meant to reflect nutrient removal within the pond without the presence of plants, yielded $28 \%$ and $31 \%$ removal of TN and TP, respectively. During the plant growth season (weeks 9-18 of the study), the two technologies showed similar nutrient removal rates: for $\mathrm{TN}: 0.026 \pm 0.0032$ and $0.025 \pm 0.0018$, and for
TP: $0.0074 \pm 0.00049$ and $0.0076 \pm 0.00065 \mathrm{~g} / \mathrm{m}^{2} /$ day for Beemat and Biohaven ${ }^{\circledR}$, respectively. For comparison, Borne (2014) reported an improvement in $\mathrm{P}$ removal of $27 \%$; and in a separate study, Borne et al. (2013) reported an improvement in $\mathrm{N}$ removal of $12 \%$, when comparing FTWs to a retention pond without them.

The values of unit area removal in this study are significantly less than those observed by Chang et al. (2012b), i.e., $0.036 \mathrm{~g} / \mathrm{m}^{2} /$ day and $0.0015 \mathrm{~g} / \mathrm{m}^{2} /$ day of $\mathrm{N}$ and $\mathrm{P}$, respectively. However, the Chang et al. study used fertilizer to increase nutrient input concentrations. That study also took place in Central Florida where the higher average temperatures (not provided) likely had a greater impact on plant processes. A study in northern Virginia, Wang and Sample (2014) reported removals of $0.013-0.025 \mathrm{~g} / \mathrm{m}^{2}$ /

Table 5

Mean cumulative removal and removal rate for total nitrogen (TN) and total phosphorus (TP) ( $n=4$ for each treatment).

\begin{tabular}{|c|c|c|c|c|c|}
\hline \multirow[b]{2}{*}{ Treatment } & \multicolumn{3}{|c|}{ Cumulative removal } & \multicolumn{2}{|l|}{ Removal rate } \\
\hline & Weeks $1-8(\mathrm{~g})^{1}$ & Weeks 9-18 $(\mathrm{g})^{\mathrm{a}}$ & Weeks $1-18(\%)$ & Weeks 9-18 (g/m² mat/day $)^{a}$ & $\mathrm{R}^{2}$ Weeks 9-18 \\
\hline \multicolumn{6}{|c|}{ Total nitrogen } \\
\hline Beemat & $0.218 \mathrm{a}$ & $0.579^{\mathrm{b}}$ & 39.6 & $0.026^{\mathrm{b}}$ & 0.993 \\
\hline BioHaven $^{\mathbb{R}}$ & $-0.040 \mathrm{~b}^{\mathrm{b}}$ & $0.539^{b}$ & 25.1 & $0.025^{\mathrm{b}}$ & 0.990 \\
\hline Control & 0.212 & 0.350 & 28.0 & 0.016 & 0.977 \\
\hline \multicolumn{6}{|c|}{ Total phosphorus } \\
\hline Beemat & $0.043 a$ & $0.165^{\mathrm{b}}$ & 47.6 & $0.007^{\mathrm{b}}$ & 0.991 \\
\hline BioHaven $^{\mathbb{R}}$ & $-0.150 \mathrm{~b}^{\mathrm{b}}$ & $0.168^{\mathrm{b}}$ & 4.07 & $0.008^{\mathrm{b}}$ & 0.990 \\
\hline Control & 0.030 & 0.107 & 31.5 & 0.004 & 0.951 \\
\hline
\end{tabular}

a Means with a different letter are significantly different from each other at $p<0.05$.

b Treatments differ from the control using Dunnett's Method. 
Table 6

Mean plant biomass characteristics at end of experiment trials in September 2013, after 126 days growth on the floating mats ( $n=4$ for each treatment).

\begin{tabular}{|c|c|c|c|c|}
\hline \multirow[b]{2}{*}{ Treatment } & \multicolumn{2}{|l|}{ Above-mat } & \multicolumn{2}{|l|}{ Below-mat/pot } \\
\hline & Biomass dry weight (g/m² mat) & Max. shoot height $(\mathrm{cm})$ & Biomass dry weight (g/m² mat) & Max. root length $(\mathrm{cm})$ \\
\hline Beemat & $142.9 \mathrm{~b}$ & $43.4 \mathrm{~b}$ & $12.4 \mathrm{~b}$ & $39.1 \mathrm{a}$ \\
\hline BioHaven $^{\circledR}$ & $188.4 \mathrm{a}$ & $48.7 \mathrm{a}$ & $25.3 a$ & $37.4 a$ \\
\hline
\end{tabular}

Means with a different letter are significantly different from each other $p<0.05$.

day and $0.0002-0.0013 \mathrm{~g} / \mathrm{m}^{2} /$ day, of $\mathrm{N}$ and $\mathrm{P}$, respectively. Our study is comparable to the aforementioned ranges.

\subsection{Plant growth and nutrient uptake}

At time of harvest, plants on the BioHaven ${ }^{\circledR}$ mats were significantly taller than those on the Beemat mats while root length was similar (Table 6). Mean biomass, above-mat and below the mat/pot, was also greater for the BioHaven ${ }^{\mathbb{R}}$ than the Beemat treatments (Table 6), possibly due to the extra nutrients present initially. The difference in root biomass is likely even greater than observed as the thickness and fibrous nature of the BioHaven ${ }^{\circledR}$ mat makes roots within the mat inaccessible for harvest. Both treatments showed greater biomass accumulation in shoot growth than in root system development (Table 6). Plant nutrient content was similar between the two treatments. The percent of $\mathrm{N}$ and $\mathrm{P}$ accumulated averaged $0.83 \% \mathrm{~N}$ and $0.15 \% \mathrm{P}$ in the shoots and $1.5 \% \mathrm{~N}$ and $0.25 \% \mathrm{P}$ in the roots. Plant uptake of nutrients varies with location, taxa and environmental factors; and therefore,should be compared carefully between studies.

\section{Conclusion}

This study investigated plant performance and $\mathrm{N}$ and $\mathrm{P}$ removal in mesocosms of two commercially available FTW technologies. On a mass basis over the study period, the BioHaven ${ }^{\circledR}$ FTW removed $25 \%$ and $4 \%$, while the Beemat removed $40 \%$ and $48 \%$ of the TN and TP, respectively. A control treatment, meant to reflect nutrient removal within the pond without the presence of plants, yielded $28 \%$ and $31 \%$ removal of TN and TP, respectively. Thus, both FTW treatment provided positive results, Beemat exceeded the control.

While mean shoot and root biomass was significantly greater for the BioHaven ${ }^{\mathbb{R}}$ than the Beemat treatment, plant nutrient content was similar between the two treatments. TN and TP levels increased with the BioHaven ${ }^{\mathbb{R}}$ mats during the plant establishment phase (weeks 1-8), which reduced the overall BioHaven ${ }^{\mathbb{R}}$ nutrient removal rate for the experimental period. This was especially notable for TP. However, during the plant growth phase (weeks 9-18), the two mat types showed similar nutrient removal rates. Both systems show potential as a BMP that could enhance nutrient removal in existing or new retention ponds. The nutrient increase observed with the BioHaven ${ }^{\mathbb{R}}$ mats during establishment may be negligible in a field-scale application on a long-term basis, considering the effects of dilution. Further research is needed to determine what is contributing nutrients initially in the BioHaven ${ }^{\circledR}$ system. These early nutrients may have contributed to the more robust growth observed in the BioHaven ${ }^{\circledR}$ treatments. Quicker nutrient removal after application, as with the Beemats could be advantageous in short growing seasons. Each system has advantages and disadvantages which should be carefully considered for each stormwater application, site characteristics and project goals. A challenge will be establishing a percentage TN and TP removal credit for the systems, for FTW systems to become a valid treatment option. Care should be taken in extrapolating these results to watershed scale applications. Larger-scale field investigations over a longer-term are needed to fully understand the mechanisms and quantify treatment performance.

\section{Acknowledgments}

This activity was also funded, in part, with an integrated, internal competitive grant from the Virginia Agricultural Experiment Station, Virginia Cooperative Extension, and the College of Agriculture and Life Sciences at Virginia Tech. Funding for this work was also provided in part, by the Virginia Agricultural Experiment Station and the Hatch Program of the National Institute of Food and Agriculture, U.S. Department of Agriculture. The authors are grateful for the support of Corey Riedel in field work and Julie Brindley in laboratory work.

\section{References}

Alberti, M., Booth, D., Hill, K., Coburn, B., Avolio, C., Coe, S., Spirandelli, D., 2007. The impact of urban patterns on aquatic ecosystems: an empirical analysis in Puget lowland sub-basins. Landscape Urban Plan. 80, 345-361.

Borne, K.E., 2014. Floating treatment wetland influences on the fate and removal performance of phosphorus in stormwater retention ponds. Ecol. Eng. 69, $76-82$.

Borne, K.E., Tanner, C.C., Fassman-Beck, E.A., 2013. Stormwater nitrogen removal performance of a floating treatment wetland. Water Sci. Technol. 68, $1657-1664$.

Burton, G.A., Pitt, R., 2002. Stormwater Effects Handbook: A Toolbox for Watershed Managers, Scientists, and Engineers. Lewis Publishers, Boca Raton, FL.

Carey, R.O., Hochmuth, G.J., Martinez, C.J., Boyer, T.H., Dukes, M.D., Toor, G.S., Cisar, J. L., 2013. Evaluating nutrient impacts in urban watersheds: challenges and research opportunities. Environ. Pollut. 173, 138-149.

Chang, N.B., Islam, K., Marimon, Z., Wanielista, M.P., 2012a. Assessing biological and chemical signatures related to nutrient removal by floating islands in stormwater mesocosms. Chemosphere 88, 736-743.

Chang, N.B., Islam, M.K., Wanielista, M.P., 2012b. Floating wetland mesocosm assessment of nutrient removal to reduce ecotoxicity in stormwater ponds. Int. J. Environ. Sci. Technol. 9, 453-462.

Chua, L.H.C., Tan, S.B.K., Sim, C.H., Goyal, M.K., 2012. Treatment of baseflow from an urban catchment by a floating wetland system. Ecol. Eng. 49, 170-180.

Cianfrani, C.M., Hession, W.C., Rizzo, D.M., 2006. Watershed imperviousness impacts on stream channel condition in Southeast Pennsylvania. J. Am. Water Resour. As. 42, 941-956.

Driver, N.E., Tasker, G.D., 1990. Techniques for estimation of storm-runoff loads, volumes, and selected constituent concentrations in urban watersheds in the United States. U.S. G.P.O.; For sale by the Books and Open-File Reports Section, U. S. Geological Survey, Denver, CO.

Fletcher, T.D., Andrieu, H., Hamel, P., 2013. Understanding, management and modelling of urban hydrology and its consequences for receiving waters: a state of the art. Adv. Water Resour. 51, 261-279.

Hamel, P., Daly, E., Fletcher, T.D., 2013. Source-control stormwater management for mitigating the impacts of urbanisation on baseflow: a review. J. Hydrol. 485, 201-211.

Hatt, B.E., Steinel, A., Deletic, A., Fletcher, T.D., 2011. Retention of heavy metals by stormwater filtration systems: breakthrough analysis. Water Sci. Technol. 64, 1913-1919.

Headley, T.R., Tanner, C.C., 2006. Application of Floating Wetlands for Enhanced Stormwater Treatment: A Review. Auckland Regional Council Technical Publication.

Headley, T.R., Tanner, C.C., 2007. Floating Wetlands for Stormwater Treatment: Removal of Copper, Zinc and Fine Particulates, in: Auckland Regional Council Technical Report 2008-030.

Headley, T.R., Tanner, C.C., 2012. Constructed wetlands with floating emergent macrophytes: an innovative stormwater treatment technology. Crit. Rev. Environ. Sci. Technol. 42, 2261-2310.

Hirschman, D., Collins, K., Schueler, T, 2008. The Runoff Reduction Method. Center for Watershed Protection and Chesapeake Stormwater Network, Ellicott City, MD.

Hubbard, R.K., Gascho, G.J., Newton, G.L., 2004. Use of floating vegetation to remove nutrients from swine lagoon wastewater. Trans. ASAE 47, 1963-1972. 
Hunt, W.F., Winston, R.J., Kennedy, S.G., Biological and Agricultural Engineering NC. State University, 2012. Evaluation of floating wetland islands (FWIs) as a retrofit to existing stormwater detention basins, p. 71.

Jayaweera, M.W., Kasturiarachchi, J.C., 2004. Removal of nitrogen and phosphorus from industrial wastewaters by phytoremediation using water hyacinth (Eichhornia crassipes (Mart.) Solms). Water Sci. Technol. 50, 217-225.

Meierdiercks, K.L., Smith, J.A., Baeck, M.L., Miller, A.J., 2010. Analyses of urban drainage network structure and its impact on hydrologic response. J. Am. Water Resour. As. 46, 932-943.

MWCOG (Metropolitan Washington Council of Governments), 1983. Urban Runoff in the Washington Metropolitan Area: Final Report, Washington, D.C. Area Urban Runoff Project. MWCOG, Washington, D.C.

Navratil, O., Breil, P., Schmitt, L., Grospretre, L., Albert, M.B., 2013. Hydrogeomorphic adjustments of stream channels disturbed by urban runoff (Yzeron River basin, France). J. Hydrol. 485, 24-36.

Nelson, E.J., Booth, D.B., 2002. Sediment sources in an urbanizing, mixed land-use watershed. J. Hydrol. 264, 51-68.

Novotny, V., 2003. Water Quality: Diffuse Pollution and Watershed Management. J. Wiley, Hoboken, NJ.

Passeport, E., Hunt, W.F., 2009. Asphalt parking lot runoff nutrient characterization for eight sites in North Carolina, USA. J. Hydrol. Eng. 14, 352-361.

Pitt, R., 2009. The National Stormwater Quality Database (NSQD, version 3.

Roseen, R., Ballestero, T., Houle, J., Avellaneda, P., Briggs, J., Fowler, G., Wildey, R., 2009. Seasonal performance variations for storm-water management systems in cold climate conditions. J. Environ. Eng.-ASCE 135, 128-137.

Shilton, A.N., 2005. Pond Treatment Technology. IWA Pub., Padstow Cornwall, UK.

Stewart, F.M., Mulholland, T., Cunningham, A.B., Kania, B.G., Osterlund, M.T., 2008 Floating islands as an alternative to constructed wetlands for treatment of excess nutrients from agricultural and municipal wastes - results of laboratoryscale tests. Land Contam. Reclam. 16, 25-33.

Tanner, C.C., Headley, T.R., 2011. Components of floating emergent macrophyte treatment wetlands influencing removal of stormwater pollutants. Ecol. Eng. 37, 474-486.

Thurston, H.W., 2006. Opportunity costs of residential best management practices for stormwater runoff control. J. Water Resour. Plan. Manage.-ASCE 132, 89-96.
U.S.EPA, 1983. Results of the Nationwide Urban Runoff Program, Volume III-Data Appendix, in: Water Planning Division (Ed.). U.S. Environmental Protection Agency, Washington, DC, p. 207.

U.S. EPA, 2010. Chesapeake Bay Total Maximum Daily Load for Nitrogen, Phosphorus, and Sediment, in: USEPA Region III (Ed.), Philadelphia, PA, p. 261. Wang, C.-Y., Sample, D.J., 2013. Assessing floating treatment wetlands nutrient removal performance through a first order kinetics model and statistical inference. Ecol. Eng. 61 (Part A), 292-302.

Wang, C.-Y., Sample, D.J., 2014. Assessment of the nutrient removal effectiveness of floating treatment wetlands applied to urban retention ponds. J. Environ. Manage. 137, 23-35.

Wang, C.-Y., Sample, D.J., Day, S.D., Grizzard, T.J., 2014. Floating treatment wetland nutrient removal through vegetation harvest and observations from a field study. Ecol. Eng. doi:http://dx.doi.org/10.1016/j.ecoleng.2014.05.018.

Wanielista, M.P., Chang, N.-B., Chopra, M., Xuan, Z., Islam, K., Marimon, Z., 2012. Floating Wetland Systems for Nutrient Removal in Stormwater Ponds. In: Kresh, E. (Ed.), Stormwater Management Academy. Civil, Environmental, and Construction Engineering Department University of Central Florida, Tallahassee, FL.

Waschbusch, R.J., 1999. Sources of phosphorus in stormwater and street dirt from two urban residential basins in Madison, Wisconsin, 1994-95. U.S. Dept. of the Interior, U.S. Geological Survey; Branch of Information Services [distributor], Middleton, Wis. ; Denver, CO.

Wen, L., Recknagel, F., 2002. In situ removal of dissolved phosphorus in irrigation drainage water by planted floats: preliminary results from growth chamber experiment. Agric. Ecosyst. Environ. 90, 9-15.

White, S.A., Cousins, M.M., 2013. Floating treatment wetland aided remediation of nitrogen and phosphorus from simulated stormwater runoff. Ecol. Eng. 61 (Part A), 207-215.

Winston, R.J., Hunt, W.F., Kennedy, S.G., Merriman, L.S., Chandler, J., Brown, D., 2013. Evaluation of floating treatment wetlands as retrofits to existing stormwater retention ponds. Ecol. Eng. 54, 254-265.

Yang, G., Bowling, L.C., Cherkauer, K.A., Pijanowski, B.C., 2011. The impact of urban development on hydrologic regime from catchment to basin scales. Landscape Urban Plan. 103, 237-247. 